Global Journal of Nursing
(ISSN:2637-4994)

\title{
Nursing recommendations to reduce the risk of Preeclampsia during prenatal care
}

\section{Elsy Guadalupe Vega-Morales ${ }^{1}$, María de los Ángeles Torres-Lagunas ${ }^{2}$, Karla Monserrat Cano-Zamora ${ }^{2}$}

${ }^{1}$ Servicios de Salud de Yucatán, Centro de Atención Temporal Siglo XXI, Coordinación Estatal de Enfermería, Mérida Yucatán, México; ${ }^{2}$ Escuela Nacional de Enfermería y Obstetricia, Universidad Nacional Autónoma de México. Ciudad de México, México.

\section{ABSTRACT}

Aim: Develop nursing recommendations based on scientific evidence, aimed at reducing the probability of developing pre-eclampsia during prenatal care.

*Correspondence to Author:

Elsy Guadalupe Vega-Morale

Material and methods: A bibliographic search was carried out Servicios de Salud de Yucatán, on the web: Medline, BVS, Cinahl and Google Scholar with the descriptors: pre-eclampsia, prenatal care, nursing with the conCentro de Atención Temporal Siglo XXI, Coordinación Estatal de Enferjunction AND and the disjunction OR. The documents with the referred descriptors were included. Two reviewers selected the articles. Conflicts were resolved by another reviewer. The methodological quality of each article was evaluated. The evidence was ranked and the recommendation was made. The Shekelle and Galvez Toro model was used for grading.

Results: 4 aspects were evidenced: risk factors, timely detection, nursing care, protective factors and recommendations.

Conclusions: Prenatal care continues to be a source of protection and control for pregnant women. Blood pressure measurement continues to be the gold standard for early detection. Nursing is a primary protective factor.

Keywords: Preeclampsia, Obstetric nursing, Prenatal care. mería, Mérida Yucatán, México.

How to cite this article:

Elsy Guadalupe Vega-Morales, María de los Ángeles Torres-Lagunas, Karla Monserrat Cano-Zamora.Nursing recommendations to reduce the risk of Preeclampsia during prenatal care.Global Journal of Nursing , 2021, 4:25.

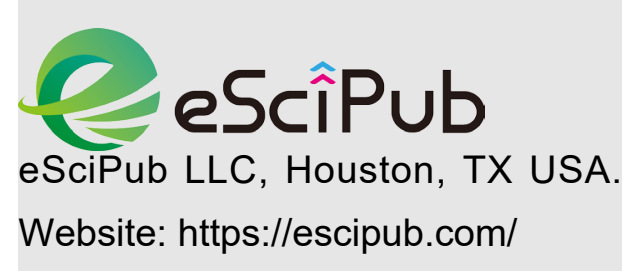


Worldwide, hypertensive disorders of pregnancy (HDP) are one of the main causes of maternal and perinatal morbidity and mortality. The risk of dying from pregnancy complications in developing countries is 14 times higher. Estimates of maternal deaths according to the World Health Organization due to HDP are $25.7 \%$ in Latin America and the Caribbean [1]. Hypertensive disorders complicate 10 million pregnancies, 80,000 maternal deaths, and 500,000 perinatals each year ${ }^{[2]}$. $10-15 \%$ (1 death per 100,000 pregnancies) is due to Preeclampsia (PE), a common complication of pregnancy characterized by hypertension and proteinuria ${ }^{[3]}$. Hypertension is considered (taking pre-pregnant blood pressure levels as a parameter), when there is an increase of $30 \mathrm{mmHg}$ in systolic pressure or $15 \mathrm{mmHg}$ in diastolic from the 20th week of gestation [4]. Termination of pregnancy is the only cure for PE [5].

In Latin America and the Caribbean it is a cause of disability ${ }^{[6,7]}$. In low-income countries the probability of dying from PE is 300 times higher [2]. The incidence ranges from 5 to $10 \%$ of all pregnancies, occurs in $10 \%$ of first-time pregnant women and in $20-25 \%$ with a history of chronic hypertension. ${ }^{[8]}$. The prevalence in developing countries is $16.7 \%$, representing around the $20-80 \%$ of maternal mortality ${ }^{[9]}$ and constitutes ${ }^{[5]}$ times the risk of perinatal mortality. According to research, this disease (PE) is considered a serious public health problem 10 due to the fact that its etiology is clearly unknown due to its multifactorial cause. Scientific literature has also evidenced an infinity of risk factors and protective elements ${ }^{[2]}$.

Likewise, PE is associated with adverse outcomes for the mother: caesarean section, stroke, encephalopathy, cardiovascular collapse, liver failure, kidney failure, placenta previa, disseminated intravascular coagulation, HELLP syndrome, pulmonary edema, respiratory distress syndrome, cerebral edema, blindness, seizures and admission to the Intensive Care Unit. It is also related to perinatal complications: premature birth, intrauterine growth restriction, fetal distress, premature placental abruption, oligohydramnios, low birth weight newborn and death [7,13]. In developing countries there is a high neonatal mortality ${ }^{[9,4]}$ and a quarter is attributed to PE ${ }^{[14]}$. Maternal deaths have been attributed to delays in the recognition of the disease, causes, preventive measures, timely transportation [15] and deficiencies in quality care in an obstetric emergency ${ }^{[6]}$.

Prevention of PE is currently not posible [16]. There is a lack of a confirmatory diagnostic test, a clear and precise tool to predict it. There is the possibility of anticipating and reducing risk simply by informing a woman of the result of a risk assessment, in order to achieve positive changes in behavior ${ }^{[17,5]}$. Maternal health is one of the Sustainable Development Goals (SDG), however, the goal of reducing maternal mortality to $75 \%$ has not yet been reached $(43 \%$ has been achieved) [1]. In developed countries it has decreased due to the quality of prenatal care ${ }^{[7]}$.

Prenatal care is an obstetric medical care program aimed at preventing complications in pregnancy and reducing maternal-fetal morbidity and mortality. It includes identifying high-risk cases, monitoring, providing education in maternal health and teaching the recognition of alarm signs and symptoms that have positive effects on the well-being of the couple ${ }^{[18]}$. The benefits range from the prevention of risks and complications in pregnancy, childbirth and the puerperium to the reduction of economic expenses for the family and the health system [19]. The quality of prenatal care is an important predictor in the perinatal outcome and not the number visits $(\geq 12)$, but in comprehensive, continuous, coordinated and multidisciplinary care. The discontinuity of prenatal care has poorer results and serious consequences [20]. Some studies indicate that health education can improve the effect of prenatal care ${ }^{[20]}$ as shown by a biopsychosocial model that reduced the incidence of maternal mortality and adverse pregnancy outcomes ${ }^{[16]}$. In prenatal care there 
are tests for the systematic detection of PE, such as the measurement of blood pressure and protein in urine, which are not harmful or expensive [21].

Information on the effect of the frequency of prenatal visits and its relationship with poor maternal-fetal outcomes is scarce. In developed countries, prenatal care is essential, for this reason its low perinatal morbidity and mortality rates ${ }^{[18]}$. In the United States includes physical examination, counseling, support psychosocial and it is recommended 7 to 12 consultations based on tradition and experiences [22]. A preventive measure is the administration of multivitamins with folic acid to help prevent preeclampsia and neural tube defects ${ }^{[23] . ~ I n ~ t h e ~}$ United Kingdom, recommendations are given to pregnant women at high risk of pre-eclampsia from the first prenatal visit, in order to make an early diagnosis, create a care plan and have intensive surveillance. For early detection, it is advisable to estimate the risk and combine the clinical history with biochemical and biophysical markers, which are involved in altered placentation and development of clinical symptoms. It is known that hypertensive disorders of pregnancy are caused by deficient placentation, genetic, environmental, nutritional and socioeconomic factors that lead to an alteration in endothelial function 10 and systemic resistance [24]. Oxidative stress is a pathogenic mechanism that leads to disease [25]. Physical activity and the prophylactic use of aspirin before the 16th week of gestation can reduce the incidence by $50 \%{ }^{[24,26]}$. Prenatal care includes: orientation, promotion of self-care, prophylaxis, diagnosis and early treatment of diseases typical of the gestation process. Nursing assumes an important role in emotional care, provides quality information, attends to feelings and often religious needs, and its care is a guarantee for the well-being of pregnant women [27].

Considering that $\mathrm{PE}$ is a worldwide public health problem and that no related nursing study has focused on concentrating the scientific literature to refer to how it can help to prevent or reduce risk factors for the disease. This review has the purpose of formulating recommendations with scientific evidence that guide and support the decisions and interventions of nurses and the rest of the health personnel, actions that are favorable and focus on the population capturing more information and can help in early detection of PE, which also has the option of choosing a timely treatment if required and / or participating in improving the quality of prenatal care. For this, the role of nursing is fundamental, from the promotion of health with respect to hygienicnutritional measures, the specific protection, which includes the timely identification of maternal and environmental risk factors: primigravity, age, smoking, obesity, etc., until early diagnosis, through prenatal control, to reduce the probability of developing or preventing the progression of the disease in its most forms serious.

OBJECTIVE: To develop nursing recommendations based on scientific evidence, aimed at reducing the probability of developing pre-eclampsia through prenatal care.

METHODS: To review the scientific literature, two experts conducted a bibliographic search on the web: Medline, Virtual Health Library (VHL), Cinahl and Google Scholar. Key descriptors were combined: pre-eclampsia, prenatal care, nursing, prevention and control, with the Boolean operators AND and OR. The results were reduced by selecting studies at 10 years, in full text, human, female, English, Spanish and Portuguese languages. This search strategy was chosen to obtain international, Latin and Mexican literature; they are also the most used resources in nursing and the indexes reviewed by the biomedical literature. Two reviewers independently selected all retrieved articles, first by title and abstract, and then full articles were reviewed. The final selections were compared and conflicts were resolved by discussion with a third reviewer. Relevant publications with care focused on preventing or reducing the probability of developing PE were included. Articles that were not related to the prevention of 
PE were excluded and those that were found duplicates, that were not located in full text or did not comply with the context of the research were eliminated. The following terms were defined for operationalization in accordance with the Health Sciences Descriptors and NOM-007-SSA22016. Prenatal care. Care provided to pregnant women with the aim of preventing complications (pre-eclampsia) and reducing the incidence of maternal and prenatal mortality [28]. This care is carried out through contacts, interviews and scheduled visits for surveillance, including information on the evolution of the pregnancy and emergency symptoms, dignified treatment and the development of a safety plan [29]. Preeclampsia. Complication of pregnancy characterized by maternal hypertension and proteinuria, with or without pathological edema after the 20th week of pregnancy ${ }^{[28]}$. Obstetric Nursing.

Care that the nurse provides to the pregnant woman before, after or during childbirth. It implies promotion, maintenance and restoration of health ${ }^{[28]}$.

Prevention and control. Used as a disease descriptor to increase human resistance against diseases (immunization), to control transmitting agents, to prevent and control environmental damage or social factors that lead to disease. Includes preventive measures in individual cases [28].

Each eligible study underwent a methodological quality assessment based on the criteria of the Spanish Critical Reading Skills Program. One point was awarded for each evaluation question that was completed. Three general aspects were considered for the quality assessment. For rigor, reference was made to the consistency of the methodology used to answer the research question. For credibility, the ability of the results to represent the study phenomenon from the subjectivity of the participants was taken into account and the usefulness of the findings in practice (qualitative) was considered for relevance. The validity of the results, the applicability in the environment, and the results themselves (quantitative) were analyzed.

For each included study, a summary table of the evidence was constructed where the keywords, the title of the research article, the database consulted, the participating organizations, the experts consulted, important background aspects, the authors, year were considered. of publication, the inclusion criteria considered, the types of references consulted, the research question, the level of evidence, sample size, sampling, design, study methodology, the critical appraisal of the results, the synthesis of the evidence and the proposed recommendation. After analyzing the results, we proceeded to rank, rank the evidence and finally formulate the strength of the recommendations. For this purpose, the Shekelle model (table No. 1) [30] was used for quantitative studies and Galvez Toro (table No. 2) ${ }^{[31]}$ for qualitative studies.

\section{RESULTS.}

From the search strategy of the literature review, 30 selected studies with information on the care of pregnant women to prevent PE resulted (Table No. 3), of which, it involved investigations that were carried out in the United Kingdom, USA, Ethiopia, India, Taiwan, Mozambique, Nigeria, Pakistan, Colombia, Egypt, China, Brazil, Amsterdam and Andean countries. The total sample of women who participated in the studies was 44,525. Gestational age ranged from 21 to 33 weeks. The participants were young women with an age range from 16 to 51 years. Most of the manuscripts were published in the English language and only some in Portuguese and Spanish. Based on the analysis of the different approaches to better understand the phenomenon, the critical reading and the summary table, 3 important aspects were derived regarding PE and the evidence was graded on risk factors, timely detection and nursing care as protective factors, which provided the basis for developing the recommendations presented.

Risk factor's. Maternal age $>35$, pre-existing hypertension (4 times more risk), family history 
of hypertension (7 times more chances), family history of diabetes (2 times more likely) and singleness were revealed as risk factors for $\mathrm{PE}$ (3 times more likely). more prone (III) ${ }^{[3]}$. Focus groups where pregnant women, couples, husbands, midwives, traditional midwives, community leaders, mothers and mothers-in-law participated, demonstrated a large gap between community perceptions and biomedical perspective in relation to PE. Thoughts, marital problems, such as abuse by in-laws, strenuous work, excessive thinking or worry, anger and sadness, depressive thoughts, lack of rest, financial and spiritual situations, cold, heredity, and salty diets were associated as causes of PE ( $\beta)^{[1,6]}$. Likewise, anemia (it is 3.5 times more common in women with $\mathrm{PE}[\mathrm{OR} 1 / 4 \mathrm{Cl} 0.46,95 \%$ : $0.24,0.90]$ (III) [11], urinary tract infections, diabetes, infections, edema, lack or loss of blood (B) [6], limited knowledge of the causes, fatigue, abuse and the warning signs (headache, heart pain, a pounding heartbeat, burning sensation in the chest, difficulty in breathing, loss of speech, weakness, dizziness, fainting, sweating, swollen feet) ( $\beta)^{[1]}$. Among other origins are the supernatural factor, internal problems, burden from housework, social responsibilities, early marriages and low blood sugar levels. From the perception of a Pakistani community, PE is caused by high blood pressure and can develop during pregnancy. It is widely associated with stress, weakness, and one of the main symptoms is headache $(\beta)^{[2]}$.

Mexican multicenter research revealed that depression was a significant finding for PE, since there is a 1 to 2 times greater risk for this disease in pregnant women who suffer from some degree of depression [OR: 1.66; $95 \% \mathrm{Cl}$ : 10582607] and 3 to 4 times higher risk when there is major depressive disorder [OR: $3.67 ; 95 \% \mathrm{Cl}$ : 1.23-10.89]. Pregnant women who sometimes reported depressive symptoms, the risk of $\mathrm{PE}$ is present 3 times higher [OR: $3.12 ; 95 \% \mathrm{Cl}: 1077$ $9,083]$. Also, violence was identified as an associated psychosocial risk factor (III) ${ }^{[32]}$.

Other studies have shown an epidemiological risk profile for adolescent women ( $<15$ years), incomplete prenatal care or lack of care $(2 / 3$ of maternal, fetal or perinatal deaths occur from this cause). It was estimated that around $8 \%$ of pregnancies do not have prenatal care at all, $35 \%$ are incomplete (<6 visits) and only $57 \%$ complete it (IIb) [7]. Likewise, it was shown that the risk increases with the Maternal overweight, short height, women from Africa and South Asia, women who conceived after the use of ovulation inducing drugs, personal or family history of PE, and coffee consumption during pregnancy were also more likely to have $\mathrm{PE}[\mathrm{OR} 1 / 4 \mathrm{Cl} 1.78,95 \%$ : $1.20,3.05]$ (IIb) [26].

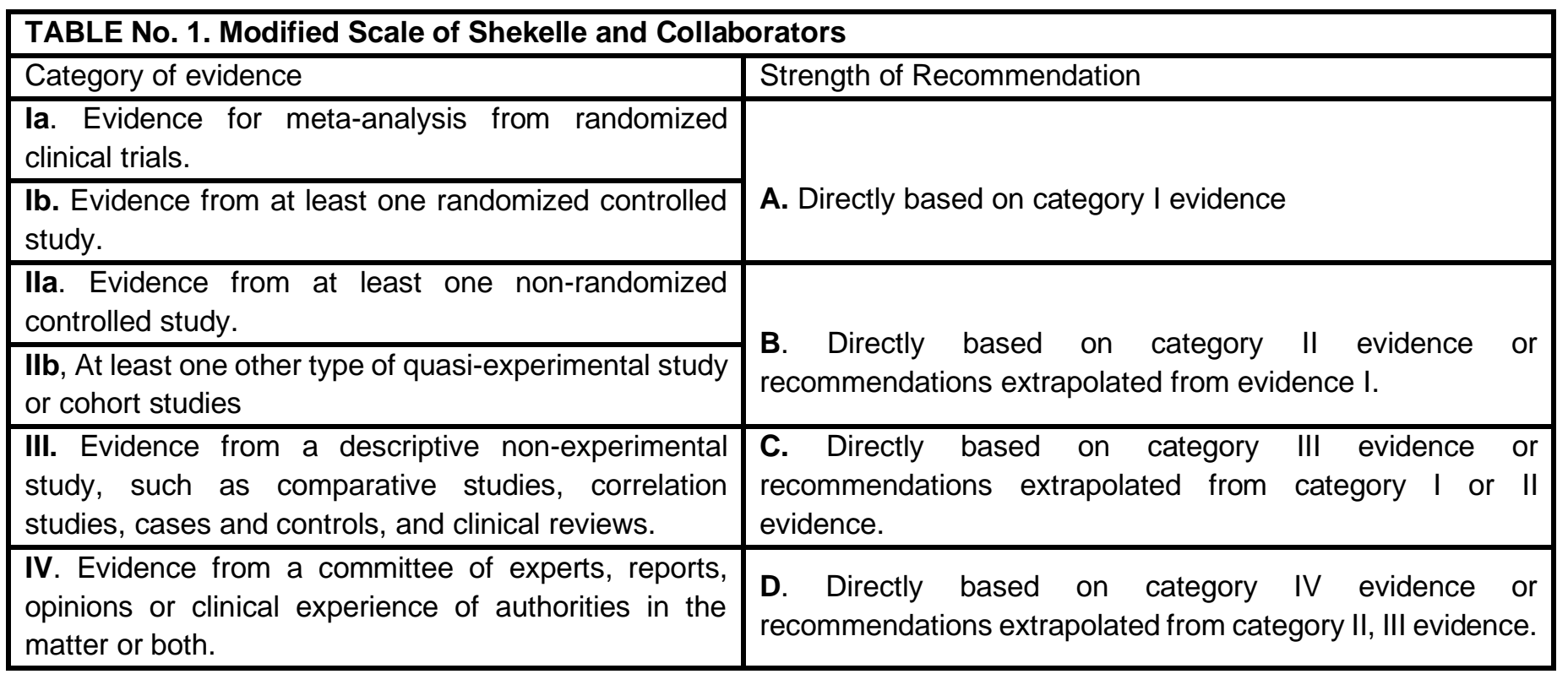




\begin{tabular}{|c|c|}
\hline Decision making * & Decision making ** \\
\hline $\begin{array}{l}\text { I would follow the } \\
\text { recommendation }\end{array}$ & Do it \\
\hline $\begin{array}{l}\text { I would consider it as a useful } \\
\text { alternative }\end{array}$ & You probably will \\
\hline $\begin{array}{l}\text { I believe that it is not the best } \\
\text { alternative because it does not } \\
\text { fit well with the problem and } \\
\text { does not give a good answer }\end{array}$ & You probably won't \\
\hline I would consider it as a curiosity & Do not do it \\
\hline \multicolumn{2}{|c|}{$\begin{array}{l}\text { * Patient, clinician, managers, planning managers. } \\
\text { ** Only the GRADE categories have been taken, since this classification is incompatible with the theoretical } \\
\text { development of the GRADE proposal, whose hierarchy is clearly positivist. } \\
\text { Source: Galvez Toro. Enfermería basada en la evidencia. Cómo incorporar la investigación a la práctica de los } \\
\text { cuidados. España: Alberto Galvez Toro; } 2007 \text {. p362. }\end{array}$} \\
\hline
\end{tabular}

\begin{tabular}{|c|c|c|c|}
\hline Identified & $\begin{array}{l}\text { PubMed }=162 \\
\text { BVS }=22 \\
\text { Cinahl }=10 \\
\text { Google Académico }=2,492\end{array}$ & Total $=2686$ & \\
\hline Screening & $\begin{array}{l}\text { PubMed }=13 \\
\text { BVS }=6 \\
\text { Cinahl }=7 \\
\text { Google Académico }=7\end{array}$ & Excluded $=2653$ & $\begin{array}{l}\text { They were eliminated due to } \\
\text { duplication, inaccessible full text } \\
\text { or were outside the context of the } \\
\text { study }\end{array}$ \\
\hline Eligibility & $\begin{array}{l}\text { PubMed = } 13 \\
\text { BVS }=6 \\
\text { Cinahl }=4 \\
\text { Google Académico }=7\end{array}$ & Included $=30$ & $\begin{array}{l}\text { Qualitative }=9 \\
{ }^{*} E C A=3 \\
\text { Descriptive }=3 \\
\text { Cohort }=4 \\
\text { Systematic reviews }=4 \\
\text { Meta-analysis }=2 \\
\text { Cases and controls }=5\end{array}$ \\
\hline
\end{tabular}

Timely detection. For the detection of PE, an investigation showed that the PREP-L (preeclampsia prediction with logistic regression), PREP (PE prediction) and PREP-S (PE survival prediction) models can be used as classification tools for risk assessment. as they showed good discrimination in external data sets, with reasonable calibration. The first provides individualized estimates of the overall risk of PE and is useful in predicting the risk of complications as a result of PE from early onset in pregnancy to postnatal discharge. The second provides robust estimates of the overall risk of maternal outcomes adverse effects due to discharge and risks at various times after diagnosis in women with early-onset PE and the third provides individual risk estimation at daily intervals from diagnosis to week 34 (Ilb) ${ }^{[5]}$. About the use of the determination of Urine protein for early detection of $\mathrm{PE}$, there is no optimal screening approach as there was no clear evidence of the performance, clinical benefits or harms of any externally validated model for predicting risk throughout pregnancy. Furthermore, that the clinical performance and the impact of the risk prediction models could not be extrapolated to the relevant settings of the patient (I) [21].

Retrospective case-control study, where 200 patients were evaluated, 100 healthy and 100 with the diagnosis, showed that the measurement of mean arterial pressure (MAP) is a promising non-invasive test and a reliable method for the prediction of PE from the first 
trimester of pregnancy, with a sensitivity of $98 \%$ and specificity $92 \%$. It was observed that patients with the diagnosis of PE presented MAP $87-106 \mathrm{mmHg}$ compared to patients without the disease with MAP 68-86 $\mathrm{mmHg}$. The results also revealed that MAP was increasing as gestational age advanced. PE was present in 95 of the patients (48\%) when MAP> $87 \mathrm{mmHg}$, of which $72(75 \%)$ presented severity criteria. PE was absent in only 2 patients (1\%). Patients who had MAP measurements $\leq 87 \mathrm{mmHg}$, PE was present in only 6 cases (3\%) and was absent in 97 (49\%) pregnant women (III) ${ }^{[33]}$.

In another investigation, $5 \%$ false positives were estimated in maternal factor screening for PE. The estimated detection rates for early PE were $33.0 \%$, for the intermediate $27.8 \%$ and for the late $24.5 \%$. Detection rates with a combination of maternal factors, biophysical and biochemical markers were 91.0, 79.4, and 60.9\%, respectively. It was also found that biophysical and biochemical markers can define the specific risk of a wide spectrum of complications during pregnancy, including: aneuploidy, fetal defects, death, miscarriage, preterm birth, fetal growth restriction, macrosomia, gestational diabetes, hypothyroidism and PE (Illb) ${ }^{[26]}$.

Nursing care as Protective factors. The following care and / or protective factors for PE were found. The work of the nursing professional is the main protective factor to identify pregnant women at risk, prevent complications and obtain a successful pregnancy outcome, since it includes education and support. In addition, the nursing staff has the knowledge and autonomy to recognize the classic signs and symptoms of PE (edema, proteinuria and hypertension) and they know how to proceed when faced with the situation. In addition, it intervenes for the assessment, diagnosis and treatment of highrisk pregnancy and provides advice on the importance of the continuity of prenatal control and adherence to medical therapy $(\alpha)^{[4]}$. Nursing has the responsibility of evaluating, stabilizing and guaranteeing the maternal and child health, as well as conducting studies, physical examinations and a complete medical history. These nursing interventions are essential to save the life of the binomial, prioritize needs according to priorities and reduce the costs of care $(\beta)^{[34]}$. Risk information and risk detection test for pre-eclampsia are considered as a protective factor, since primigravidas demonstrate acceptance and the typology "managers in danger" have an internal sense of control, focus on the risk of pre-eclampsia and seek information, they also have positive behavior changes, cognitive reappraisal, survival mechanisms and greater participation in surveillance for risk reduction, in relation to the typology "fear managers" (a) [17]. The administration of multivitamins containing folic acid effectively reduces the homocysteine that causes PE disorder (la) [23]. Folate concentrations in maternal serum have been associated as a protective factor for preeclampsia, while concentrations of ho Mocysteine was associated as a risk factor in a Colombian study with 17,074 pregnant women (III) ${ }^{[35] .}$

Vitamin C and E supplements in high-risk pregnant women with a low nutritional status do not prevent PE (IIb) [25]. Physical activity in leisure time during early pregnancy in nulliparous women is not associated with a reduction in the incidence of preeclampsia [OR $0.43 ; 95 \% \mathrm{Cl} 0.17-1.10]$ or gestational hypertension [OR $0.78, \mathrm{Cl} 0.36-1.69]$ (llb) [24], however, it is possible to encourage the practice of exercise. Increased consumption of fruit or vegetables at least three times a week during pregnancy [OR $1 / 4 \mathrm{Cl} 0.51,95 \%: 0.29,0.91]$ and daily folic acid intake [OR $1 / 4 \mathrm{Cl} 0.16,95 \%$ : 0.08 , $0.29]$ (III) ${ }^{[11]}$ are protective factors against PE. Likewise, the restriction of nutritional supplements (calcium, antioxidants), rest, low doses of aspirin and self-treatment of vaginal infections are considered important. The most economical, effective and universal way to prevent PE is a social system that guarantees adequate nutrition for pregnant women and access to an adequate system of prenatal care 
(III) [10]. Prenatal care must be of quality and include complete medical history, as well as several physical and clinical examinations, to guarantee a healthy pregnancy and delivery for the mother and the newborn (III) [22]. The failure in the quality of care is due to the absence of the pregnant woman for care prenatal $(\beta)$ [13]. Standard, multidisciplinary, cooperative, coordinated, comprehensive and wellestablished prenatal hospital care has more favorable results in terms of maternal complications and fetal evaluations in relation to conventional care. Discontinuation of prenatal care is a risk factor for relatively poorer pregnancy outcomes, such as low birth weight and premature birth [OR 3.26 ; 95\%, 1.56-6.81; p $=0.002](\mathrm{llb}){ }^{[19]}$. Women who do not attend an adequate number of prenatal visits (more than 4 visits) are 12 times more likely to have a poor maternal outcome [OR 12, Cl $4.5-32.1$; $\mathrm{P}$ $<0.0001]$ and 53 times greater risk of poor fetal outcome [OR 53.3; IC 7-408.8; P <0.0001] (III) 18. In Mexico it was evidenced that there is a 7.4 times higher risk of $\mathrm{PE}$ when pregnant women have less than 5 prenatal visits [OR: 7.42 ; $95 \%$ Cl: 2.85 - 19.33] (III) ${ }^{[32] .}$

The introduction of a comprehensive prenatal care program based on the biopsychosocial model can reduce the incidence of maternal mortality by up to $23 \%$ ( $p=0.024$ ), $45 \%$ of those caused by $\mathrm{PE}$ and $34.4 \%$ of complications in childbirth. Early identification of PE, treatment of urinary tract infections and gestational diabetes in conjunction with nutritional supplements and social support $(p=0.042)$, improve pregnancy outcomes. Women with private health insurance with access to prenatal care have a lower incidence of developing PE (IIb) ${ }^{[16]}$. Incentives are not an effective tool to increase the early use and quality of prenatal care (la) ${ }^{[19]}$. Preventive measures focus on the quality of care provided to you provides the pregnant woman with nutrition, support from partners, complete and clear information about the condition ( $\beta)^{[6]}$, regular visits to prenatal care, avoiding bitter drinks, strenuous work ( $\beta$ ) [1] and support to reduce stress ( $\beta$ ) 2. Religion plays an important

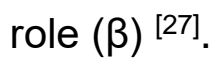

Recommendations. In the context of the evidence found, nursing recommendations were made for health promotion, specific protection, early diagnosis and protective care in order to reduce the risk and limit the damage caused by PE (see Table No. 4).

\begin{tabular}{|c|c|c|}
\hline $\begin{array}{l}\text { Prevention } \\
\text { Levels }\end{array}$ & Recommendations & Force \\
\hline \multirow{7}{*}{$\begin{array}{l}\text { Health } \\
\text { promotion }\end{array}$} & $\begin{array}{l}\text { Make every pregnant woman aware of the risk of developing PE after the 20th } \\
\text { week of gestation }\end{array}$ & A \\
\hline & Promote prenatal control to a number of 12 prenatal visits & B \\
\hline & To promote understandably, the risk of $\mathrm{PE}$, preferably in the primigravida. & $\begin{array}{l}\text { I would follow the } \\
\text { recommendation }\end{array}$ \\
\hline & Promote mental health and family support in all pregnant women & C \\
\hline & $\begin{array}{l}\text { Provide information to the pregnant woman and the family regarding nutrition, } \\
\text { hygiene measures, and health services, which allow them to choose healthy } \\
\text { actions in a responsible way }\end{array}$ & B \\
\hline & $\begin{array}{l}\text { Inform pregnant women about risk factors for PE, such: advanced age (> } 35 \\
\text { years), history of hypertension, depression, stress, and anemia }\end{array}$ & C \\
\hline & $\begin{array}{l}\text { Inform pregnant women about risk factors such as pregnancy in minors }(<15 \\
\text { years), obesity, family history of PE, lack of prenatal care, or noncomplete } \\
\text { prenatal care, use of hormones, and consumption of coffee }\end{array}$ & $\mathrm{B}$ \\
\hline
\end{tabular}




\begin{tabular}{|c|c|c|}
\hline & $\begin{array}{l}\text { Guide over other risk factors such as DM, infections, violence, and domestic } \\
\text { work overload }\end{array}$ & $\begin{array}{l}\text { I would consider it as } \\
\text { a useful alternative }\end{array}$ \\
\hline & $\begin{array}{l}\text { Inform pregnant women about warning signs (headache, edema of the pelvic } \\
\text { limbs, respiratory distress) }\end{array}$ & $\begin{array}{l}\text { I would consider it as } \\
\text { a useful alternative }\end{array}$ \\
\hline \multirow{14}{*}{$\begin{array}{l}\text { Specific } \\
\text { Protection }\end{array}$} & Every pregnant woman must be evaluated by a nursing professional & $\begin{array}{l}\text { I would follow the } \\
\text { recommendation }\end{array}$ \\
\hline & $\begin{array}{l}\text { Identify maternal risk factors, predictors for preeclampsia in all pregnant } \\
\text { women }\end{array}$ & B \\
\hline & $\begin{array}{l}\text { Identify psychosocial risk factors (violence, stress, depression, and lack of } \\
\text { family support) for pre-eclampsia }\end{array}$ & $\mathrm{C}$ \\
\hline & $\begin{array}{l}\text { Detect women with high-risk factors for PE for referral to a multidisciplinary } \\
\text { care unit }\end{array}$ & B \\
\hline & Quantify and monitor BMI at each prenatal visit & B \\
\hline & Early identification of gestational diabetes & B \\
\hline & Detect and treat oral, vaginal, and urinary infections & $\begin{array}{l}\text { I would consider it as } \\
\text { a useful alternative. }\end{array}$ \\
\hline & $\begin{array}{l}\text { Recommend the intake of multivitamin supplements with folates in the diet of } \\
\text { pregnant women }\end{array}$ & A \\
\hline & Encourage daily physical activity of mild to moderate intensity & $\mathrm{B}$ \\
\hline & Prescribe nutrition with increased consumption of fruits and vegetables & C \\
\hline & Provide quality care, which guarantees a healthy pregnancy & $\begin{array}{l}\text { I would consider it as } \\
\text { a useful alternative }\end{array}$ \\
\hline & Provide prenatal care, based on the biopsychosocial model & B \\
\hline & Channel specialist professionals, in case of detecting psychosocial care needs & $\begin{array}{l}\text { I would consider it as } \\
\text { a useful alternative }\end{array}$ \\
\hline & Encourage the participation of men in prenatal and family consultations & $\begin{array}{l}\text { I would consider it as } \\
\text { a useful alternative }\end{array}$ \\
\hline \multirow{5}{*}{$\begin{array}{l}\text { Early } \\
\text { Diagnosis }\end{array}$} & $\begin{array}{l}\text { Assess the risk of PE through a complete medical history and physical } \\
\text { examination, from the first prenatal visit }\end{array}$ & C \\
\hline & $\begin{array}{l}\text { Teach the pregnant woman and the family, during the prenatal check-up, to } \\
\text { measure and monitor their blood pressure figures at home }\end{array}$ & $\begin{array}{l}\text { I would consider it as } \\
\text { a useful alternative }\end{array}$ \\
\hline & $\begin{array}{l}\text { Measure and monitor mean arterial pressure at each prenatal visit (should } \\
\text { remain } \leq 87 \mathrm{mmHg} \text { ) }\end{array}$ & C \\
\hline & $\begin{array}{l}\text { Determine protein in the urine, in all pregnant women from the 20th week of } \\
\text { gestation }\end{array}$ & A \\
\hline & $\begin{array}{l}\text { Identify the presence of alarm signs, such as hypertension, edema, severe and } \\
\text { persistent headache, epigastric pain, pain in the right upper quadrant, nausea, } \\
\text { or vomiting. }\end{array}$ & $\begin{array}{l}\text { I would consider it as } \\
\text { a useful alternative }\end{array}$ \\
\hline
\end{tabular}

\section{DISCUSSION}

Despite the fact that the prevention of PE has not been possible due to the lack of knowledge of the etiology and the lack of a confirmatory diagnostic test, there is the possibility of evaluating and predicting the risk through factors and routine control tests for early detection.

Official Mexican documents such as the Clinical Practice Guidelines and Official Standards that refer to prenatal care of pregnancy and the prevention of PE, were used with the specific nursing approach to compare the results of this review.

There is no doubt that high-value actions can be useful to reduce risk factors for PE during prenatal consultation, so there is agreement on promoting prenatal care and informing all pregnant women of the possibility of developing PE after the 20th week of gestation. This information is consistent with that referred to in 
the review, but we did not find the ideal number of consultations (twelve) that women should have to identify and reduce risks.

Regarding the identification of risk factors, it was found of essential interest to identify psychosocial risk factors for PE. The clinical practice guidelines do not propose it as prenatal care. Although it is fully agreed that patients with high risk factors for PE should be referred for specialized care ${ }^{[31,36]}$.

Likewise, in accordance with the Official Mexican Standard (NOM-007-SSA2-2016) [31,36] to contemplate prescribing rest for stress reduction since this risk factor for PE was also consistent in the literature consulted.

Correspondence was found regarding the information that should be given to the pregnant woman regarding the alarm data in each consultation such as headache, hypertension and edema, among others, activity included as part of the protection of the pregnant woman with the intention of refer cases early to specialized maternal health services.

Although no information was found in the literature review regarding the presence of epigastric pain, right upper quadrant pain, nausea, vomiting, as clinical manifestations that increase the diagnostic certainty of PE, even without demonstrating proteinuria, ${ }^{[33,37]}$ it is considered a recommendation of utmost importance since the affected woman deserves referral to a health institution for serious suspicion of the condition [34].

It is agreed that the sign of arterial hypertension after the 20th week of gestation with $\mathrm{T} / \mathrm{A} \geq 140$ $90 \mathrm{mmHg}$ and Proteinuria is essential to establish the diagnosis of PE [34,36,37,38,39] however, it is thought that It is more positive to consider the pre-pregnant blood pressure levels or before the 20th week of gestation to suspect the diagnosis when there is an increase of 30 $\mathrm{mmHg}$ in systolic pressure or $15 \mathrm{mmHg}$ of diastolic pressure, because short women could manifest low blood pressure. It is also believed that it is important to consider MAP monitoring as described in the PE prediction review. Evidence was found about the measurement of blood pressure at home or outpatient, to prevent $\mathrm{PE}$, however, we did not find recommendations related to teaching the user and family the appropriate way to measure blood pressure at home or monitoring of readings, such an educational action being important for the prevention of PE and its complications [39].

Likewise, it is considered important to recommend to pregnant women the quantification and monitoring of weight, height and body mass index (BMI) in each consultation and nutritional hygiene measures, although it was not associated with PE in the consulted evidence, since the being overweight and / or obese are risk factors for PE and gestational diabetes [36].

From the perspective of the discipline, it is convenient to encourage the addition of multivitamin supplements with folates in the diet of pregnant women since various studies relate the deficit of vitamins and folic acid with the elevation of homocysteine levels (an amino acid that the body uses to produce proteins) in plasma, which is responsible for various obstetric pathologies such as PE, abortions, malformations, intrauterine deaths, among other things40. This care was not reported in the guides either.

\section{CONCLUSIONS.}

After analyzing this entire range of recommendations, we conclude with four essential premises: nursing promotion, prenatal control, identification of risk factors and blood pressure measurement continue to be the gold standard for the protection and early detection of PE. Finally, a proposal of key interventions for the care of pregnant women is made (Table No. 4)

\section{Limiting.}

The included studies scored well (above 80 points); they were generally at moderate risk of bias; Some limitations found were: the restricted generalization of the qualitative findings, which 
cannot be predicted for similar studies. Some research could not be found in its original form.

\section{References.}

[1]. Boene $H$, Vidler $M$, Sacoor $C$, Nhama $A$, Nhacolo A, Bique C, et al. (2016). Community perceptions of pre-eclampsia and eclampsia in southern Mozambique. Reproductive Health.13(Suppl 1):33. doi.org/10.1186/s12978016-0135-y

[2]. Raza A, Najam R, Sheikh S, Zaidi S, Salam R, Sawchuck D, et al. (2016). Community's perceptions of pre-eclampsia and eclampsia in Sindh Pakistan: a qualitative study. Reproductive Health. 13(Suppl 1):36: doi.org/10.1186/s12978-016-0136-x.

[3]. Gizachew AT, Abebe T and Tadesse A. (2015). Preeclampsia and associated factors among pregnant women attending antenatal care in Dessie referral hospital, Northeast Ethiopia: a hospital-based study. BMC Pregnancy Childbirth. 15 (73):1.

[4]. Alves E, Ferreira L, Castro R. (2010). Knowledge and attitudes of nurses towards pregnant women with symptoms of hypertensive disorders of pregnancy (HDP) were gathered in Basic Health Units (UBS)J Health Sci Inst. 28(2):151-3. https://bit.ly/2MppOqy.

[5]. Thangaratinam S, Allotey J, Marlin N, Mol B, Dadelszen P, Ganzevoort W, et al. (2017). Development and validation of Prediction models for Risks of complications in Early-onset Pre-eclampsia (PREP): a prospective cohort study. GMS Health Technol Assess. 1(18). https://bit.ly/2nXH3k4.

[6]. Akeju D, Vidler M, Oladapo O, Sawchuck D, Qureshi R, Dadelszen P, et al. (2016). Community perceptions of pre-eclampsia and eclampsia in Ogun State, Nigeria: a qualitative study. Reproductive Health. 13(Suppl1):57. doi.org/10.1186/s12978-016-0134-z.

[7]. Cruz I, Merencio W, Sánchez G., Ferreira N, Almeida F, Vieira J. (2015). Maternal and fetal outcome in women with hypertensive disorders of pregnancy: the impact of prenatal care. Ther Adv Cardiovasc Dis. 9(4):140-6. https://bit.ly/2nZ1LzL

[8]. Shamsi U, Hatcher J, Shamasi A, Zuberi N, Qadri Z, Saleem S. (2010). A multicentre matched case control study of risk factors for Preeclampsia in healthy women in Pakistan. BMC Womens Health. 10(1). https://bit.ly/2M13NLb
[9]. Bezerra P, Leao M, Queiroz J, Melo E, Pereira $F$, Nóbrega M, et al. (2010). Family history of hypertension as an important risk factor for the development of severe preeclampsia. Acta Obstet Gynecol Scand. 89(5):612-7. https://bit.ly/2QztC5I

[10]. López P, García R, Reyes L, Ruíz Silvia. (2009). Appropriate prenatal care system: the best way to prevent preeclampsia in Andean countries. Colomb Med. 40(2):226-30. https://bit.ly/2PpnFJ8.

[11]. Lima N, Pinheiro A, do Ceu I. (2013). Representaciones sociales de las madres sobre la hipertensión gestacional y parto prematuro. Rev Latino-Am Enfermagem. 21(3):337-44. https://bit.ly/2MNe40t

[12]. Mulualem E, Fantu A, Melkamu B, Anemaw A. (2015). Diet and Pre-eclampsia: A Prospective Multicentre Case-Control Study in Ethiopia. Elsevier. 31(6):617-24. doi.org/10.1016/j.midw.2015.03.003

[13]. Sodré G, Nascimento GI, Duarte C, RicarteM, Santos M. (2017). Assistência de enfermeiros na síndrome hipertensiva gestacional em hospital de baixo risco obstétrico. CUID Rev. 8(2):1561-72. doi.org/10.15649/cuidarte.v8i2.374

[14]. Goldenberg RL, McClure EM, Macguire ER, Kamath BD, Jobe AH. (2011). Lessons for lowincome regions following the reduction in hypertension-related maternal mortality in highincome countries. Int J Gynaecol Obstet. 113(2):91-5. doi.org/10.1016/j.ijgo.2011.01.002

[15]. Vidler M, Umesh C, Geetanjali K, Ramadurg U, Karadiguddi C, Sawchuck D, et. al. (2016). Community perceptions of pre-eclampsia in rural Karnataka State, India: a qualitative study. Reproductive Health.13(Supl1):35. doi.org/10.1186/s12978-016-0137-9

[16]. Herrera JA, Herrera-Medina R, Herrera-Escobar JP, Nieto-Díaz A. (2014). Reduction of maternal mortality due to preeclampsia in Colombia--an interrupted time-series analysis. Colomb Med (Cali). 30;45(1):25-31. PMID: 24970956; PMCID: PMC4045224. https://bit.ly/2OWA2eS

[17]. Harris JM, Franck L, Green B, Michie S. (2014). The psychological impact of providing women with risk information for pre-eclampsia: A qualitative study. Midwifery. 30(12):1187-95. doi.org/10.1016/j.midw.2014.04.006

[18]. Mohamed A, El-Sayed E, Martínez M, Torrejón R. (2016). Antenatal care visits during pregnancy and their effect on maternal and fetal outcomes in pre-eclamptic patients. J Obstet 
Gynaecol

Res.42(9):1102-10.

doi.org/10.1111/jog.13031

[19]. Hasta SR , Everetts D, Haas DM. (2015). Incentives for increasing prenatal care use by women in order to improve maternal and neonatal outcomes. Cochrane Libr. 12(CD009916):1465-88.

doi.org/10.1002/14651858.CD009916.pub2

[20]. Liu C. M, Chang S. D, Cheng P. J. (2012). Relationship between prenatal care and maternal complications in women with preeclampsia: Implications for continuity and discontinuity of prenatal care .Taiwán J Obstet Gynecol. 51(4):576-82. doi.org/10.1016/j.tjog.2012.09.013

[21]. Henderson J, Thompson J, Burda B, Burda B, Cantor A, Beil T, et al. (2017). A Systematic Evidence Review for the U.S. Preventive Services Task Force. 148:[aprox 35 pp]. https://bit.ly/2w1tbcH

[22]. Adam J, Zolotor M, Carlough M. (2014). Update on Prenatal Care. Am Fam Physician. 89(3):199-208. https://bit.ly/2BsasMN

[23]. Yang X, Hui C, Du Y, Wang S, Wang Z. (2016). Periconceptional folic acid fortification for the risk of gestational hypertension and preeclampsia: a meta-analysis of prospective studies. Maternal \& Child Nutrition. 12:669-79. doi.org/10.1111/mcn.12209

[24]. Vollebregt K, Wolf $\mathrm{H}$, Boer K, Van Der Wal M, Vrijkotte T, Bonsel G. (2010). Does physical activity in leisure time early in pregnancy reduce the incidence of preeclampsia or gestational hypertension?. Acta Obstet Gynecol Scand. 89:261-7. doi.org/10.3109/00016340903433982

[25]. Villar J, Purwar M, Merialdi M, Zavaleta N, NhuNgoc N, Anthony J, et al. (2009). World Health Organisation multicentre randomised trial of supplementation with vitamins $\mathrm{C}$ and $\mathrm{E}$ among pregnant women at high risk for pre-eclampsia in populations of low nutritional status from developing countries. BJOG. 116:780-8.: doi.org/10.1111/j.1471-0528.2009.02158.x.

[26]. Akolekar R, Syngelaki A, Sarquis R, Zvanca M, Nicolaides K. (2011). Prediction of early, intermediate and late pre-eclampsia from maternal factors, biophysical and biochemical markers at 11-13 weeks. Prenat. Diagn.31(1):66-74. doi.org/10.1002/pd.2660.

[27]. Pinho A, Pamplona V, García C. (2010). Sentimientos y percepciones de mujeres en el ciclo embarazo-puerperio que sobrevivieron a una morbosidad materna grave. Rev Latino-Am Enfermagem. 18(6):1187-94. https://bit.ly/2GExbTi
[28]. Descriptores en Ciencias de la Salud: DeCS [Internet]. ed. 2017. Sao Paulo (SP): BIREME / OPS / OMS. 2017 [actualizado 2017 May 18; citado 2017 Jun 13]. Disponible en: http://decs.bvsalud.org/E/homepagee.htm

[29]. NORMA Oficial Mexicana -007-SSA2-2016, Para la atención de la mujer durante el embarazo, parto y puerperio, y de la persona recién nacida. http://www.dof.gob.mx/nota_detalle.php?codigo $=5432289 \&$ fecha $=07 / 04 / 2016$

[30]. Shekelle PG, Woolf SH, Eccles M, Grimshaw J. Guías clínicas: desarrollo de directrices. BMJ. 1999; 318 (7183): 593-6

[31]. Gálvez Toro, A. (2007). Enfermería Basada en la Evidencia. Cómo incorporar la investigación a la práctica de los cuidados. Fundación Index: Granada.

[32]. Torres MA, Vega EG, Vinalay I, Cortaza L, Alfonso L, (2018). Factores de riesgo psicosociales asociados a preeclampsia en mujeres mexicanas: análisis comparado en tres Estados. Enfermería Universitaria. 15(3)226-43. http://dx.doi.org/10.22201/eneo.23958421e.201 8.3.65987

[33]. Palacios Y, Latan J, Rivera L, Cabrera C, Pacheco R, Cabrera C. (2018). Relación entre la presión arterial media y el desarrollo de Preeclampsia. Rev. Latin. Perinat. 21 (1). https://bit.ly/3ea6WpW

[34]. Prevención, diagnóstico y tratamiento de la Preeclampsia en segundo y tercer nivel de atención, Instituto Mexicano del Seguro Social; Ciudad de México, 16/03/2017. Disponible en: http://imss.gob.mx/profesionales-salud/gpc

[35]. Serrano, Norma C; Quintero-Lesmes, Doris Cristina; Becerra-Bayona, Silvia; Guio, Elizabeth; Beltran, Mónica; Paez, María C; Ortiz, Ricardo. (2018). Association of pre-eclampsia risk with maternal levels of folate, homocysteine and vitamin B12 in Colombia: A case-control study. PLoS One. 13(12): e0208137. https://pesquisa.bvsalud.org/portal/resource/es/ mdl-30521542

[36]. Control prenatal con enfoque de riesgo. México: Secretaría de Salud, 2009. www.cenetec.salud.gob.mx/interior/gpc.htm

[37]. Detección, Diagnóstico y Tratamiento de Enfermedades Hipertensivas del Embarazo. Guía de Evidencias y Recomendaciones: Guía de Práctica Clínica. México, IMSS; 2017. Disponible en:

http://www.imss.gob.mx/profesionalessalud/gpc

[38]. Detección y diagnóstico de enfermedades hipertensivas del embarazo. México: Secretaría 
Elsy Guadalupe Vega-Morales et al., GJON, 2021, 4:25

de Salud, 2010. Disponible en:

www.cenetec.salud.gob.mx/interior/gpc.html

[39]. Barrera Cruz A, Román Maeda S, Rodríguez Loreto E, Villalaz Ureña A. Guía de práctica clínica intervenciones de enfermería en la paciente con preeclamsia/eclampsia. Mèxico: Secretaria de Salud, 2011. http://www.cenetec.salud.gob.mx/descargas/gp c/CatalogoMaestro

[40]. María Ruiz Caballero. (2011). Homocisteína en el embarazo: candidato a prueba de cribado.
REDUCA
Vol.
3 ,
Núm.
3

http://revistareduca.es/index.php/reduca-

enfermeria/article/view/746 